\title{
Simplified Theorem in Number System Conversion
}

\author{
Jennifer Bagulaya-Abogaa \\ College of Computer Studies, \\ Eastern Samar State University \\ Borongan City, Eastern Samar, \\ Philippines
}

\begin{abstract}
Numbers found on computer were represented in 0 s and $1 \mathrm{~s}$ or bits, from binary digits. These numbers are identified from their bases. They can be converted from one number to another number. The researcher innovate simplified theorem in conversion of these numbers in simple mathematical operation. Conversion of these numbers were presented in conventional and exhausted manner in most references, it involves two or more variety of operation. This innovative tool is very easy to learn and very efficient. Three attributes; usability, reliability, and efficiency were employed to ascertain the applicability of the simplified theorem as tool for instruction.
\end{abstract}

\section{General Terms}

Conversion, Conventional, Decimal, Simplified

\section{Keywords}

Binary, Base, Efficiency, Hexadecimal, Octal, Innovative Tool, Number System, Reliability, Simplified Theorem, Usability.

\section{INTRODUCTION}

Education is a light that shows the mankind the right direction to surge. The purpose of education is not just making student literate but adds rationale thinking, knowledge ability, and self sufficiency. When there is a willingness to change, there is hope for progress in any field. Creativity can be developed and innovation benefits both students and teachers (Damodharanan, 2013).

There are many innovative and interesting proof techniques in the history of mathematics. One that comes to mind is the technique of diagonalization introduced by Cantor in his work on cardinalities of sets. Diagonalization is powerful, as it lets us prove non-existence results. Diagonalization has been used e.g. in the theory of computational complexity to show "gap theorems". It is also the key to proving Godel's famous incompleteness theorem, (Hyttel, 2013).

Another theory developed in the discipline of mathematics is the multiple intelligence by Gardner. Howard Gardner (1991, p 12) argues in favor of approaching a discipline in a variety of ways that accommodate multiple learning styles, thereby facilitating the learning process more effectively, "The broad spectrum of students-and perhaps the society as a wholewould be better served if disciplines could be presented in a numbers of ways and learning could be assessed through a variety of means." One strategy involves approaching multiplication facts in different way. Instead of having students commit all the multiplication facts to memory through repetition, the teacher could write one multiplication fact on the board (e.g. $6 \times 4=24)$. Then the students could begin working with this fact in a variety of ways. The logical/mathematical learners would be able to write down all eight facts in the family, focusing on the logical relations of the facts. The verbal-linguistic learners would be able to write the multiplication fact using only words. They would also be able a word problem that requires the multiplication fact given in order to solve the word problem. The Visual-spatial learners would be able to draw a picture to represent the multiplication fact (Gardner, 1991).

Number system consist of four numbers; binary numbers, decimal numbers, octal numbers, and hexadecimal numbers. Numbers were clearly presented in Discrete Structures and Discrete Mathematics computing courses.

Khan (2013) narrated, "digital computer represents all kinds of data and information in the binary system. Binary Number System consists of two digits 0 and 1 . Its base is 2 . Each digit or bit in binary number system can be 0 or 1 . A combination of binary numbers may be used to represent different quantities like 100. The Decimal Number System consists of ten digits from 0 to 9 . These digits can be used to represent any numeric value. The base of decimal number system is 10 . It is the most widely used number system. Octal Number System consists of eight digits from 0 to 7 . The base of octal system is 8 . Each digit position in this system represents a power of 8 . Any digit in this system is always less than 8 . Octal number system is used as a shorthand representation of long binary numbers. The Hexadecimal Number System consists of 16 digits from 0 to 9 and A to F. The alphabets A to $\mathrm{F}$ represent decimal numbers from 10 to 15 . The base of this number system is 16 . Each digit position in hexadecimal system represents a power of $16 . "$

These number can be converted from one number to another. Conversion of these numbers are presented in conventional and exhausted manner in most references, it involves two or more variety of operations. The researcher innovate simplified theorem in conversion for these numbers in single mathematical operation. Hence, conformed this study.

\section{OBJECTIVES}

The study aimed to (1) come-up a simplified theorem in number system conversion; and (2) evaluate the innovative tool using the attributes of reliability, usability, and efficiency.

\section{SIMPLIFIED THEOREM}

General Instruction: Give attention the 1s or 1 bit.

Simplified theorem. Express the decimal value per binary number, add those with 1s.

$\begin{array}{rrrr}1 & 1 & 1 & 1 \\ \ldots 8 & 4 & 2 & 1\end{array}$


From:

$$
\ldots 2^{3}=8 ; 2^{2}=4 ; 2^{1}=2 ; 2^{0}=1
$$

(1.) Conversion of binary numbers to decimal numbers.

Apply the theorem.

Example: $1001_{2}=(?)_{10}$

$$
\begin{array}{lccc}
1 & 0 & 0 & 1 \\
8 & 4 & 2 & 1 \\
= & 8+1=9 \\
\text { Therefore; } 1001_{2}=9 & =9
\end{array}
$$

(2) Conversion of binary numbers to octal numbers.

Cluster the bits in 3bits/group, in right to left direction, and add 0 s for the missing bit in to complete the group. Apply the theorem.

Example: $1110012=(?) 8$

$\begin{array}{llllll}111 & 001= & & & \\ 1 & 1 & 1 & 0 & 0 & 1 \\ 4 & 2 & 1 & 4 & 2 & 1 \\ =4+2+1=7 & & =1 & \end{array}$

(3) Conversion of binary numbers to hexadecimal numbers.

Apply conversion (2) using 4 bits/groups.

Example: $100111102=(?) 16$

$\begin{array}{llll}1 & 0 & 0 & 1 \\ 8 & 4 & 2 & 1 \\ =8+1=9 & \\ 1 & 1 & 1 & 0 \\ 8 & 4 & 2 & 1 \\ =8 & +4+2=14(\mathrm{E}) \\ \text { Therefore; } 10011110_{2}=9 \mathrm{E}_{16}\end{array}$

(4) Conversion from decimal numbers to binary numbers. Apply theorem, write $1 \mathrm{~s}$ below the decimal numbers, such that the sum is equal to the given decimal numbers.

Example: $25_{10}=(?)_{2}$

\begin{tabular}{lcccc}
16 & 8 & 4 & 2 & 1 \\
1 & 1 & 0 & 0 & 1 \\
\multicolumn{7}{l}{ Therefore; $25_{10}=11001_{2}$} &
\end{tabular}

(5) Conversion from decimal numbers to octal numbers. Express the binary numbers of the given decimal, and apply conversion (2).

Example: $2510=(?) 8$

$\begin{array}{lllll}\begin{array}{lll}11001=011 & 001\end{array} & & & \\ 0 \quad 1 & 1 & 0 & 0 & 1 \\ 4 \quad 2 & 1 & 4 & 2 & 1 \\ =2+1=3 & & =1\end{array}$

(6) Conversion from decimal numbers to hexadecimal. Express the binary values of the given decimal, Apply conversion (3).

Example: $2510=(?) 16$

$\begin{array}{llll}11001 & & \\ 0001 & & & 1001 \\ 0 & 0 & 0 & 1\end{array}$

$$
\begin{array}{llll}
8 & 4 & 2 & 1=1 \\
1 & 0 & 0 & 1 \\
8 & 4 & 2 & 1=8+1=9
\end{array}
$$

Therefore; $25_{10}=19_{16}$

(7) Conversion from octal numbers to binary numbers. Apply conversion (4).

Example: $4618=(?) 2$

$$
\begin{array}{lll}
4 & 2 & 1 \\
1 & 0 & 0=4 \\
4 & 2 & 1 \\
1 & 1 & 0=6 \\
4 & 2 & 1 \\
0 & 0 & 1=1 \\
\text { Therefore; } 461_{8}=100110001_{2}
\end{array}
$$

(8) Conversion from octal numbers to decimal numbers. Apply conversion (7), and conversion (1).

Example: $358=(?) 10$

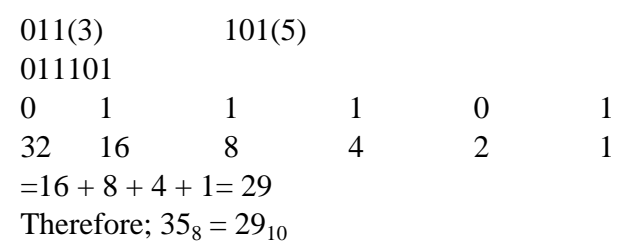

(9) Conversion from octal numbers to hexadecimal numbers.

Apply conversion (7), and conversion (3).

Example: $358=(?) 16$

$011101=$ re-group in right to left, four bits/group, add 0s to complete the group.

\begin{tabular}{llll}
0011 (group2 & ) & \multicolumn{1}{c}{1101 (group1) } \\
0 & 0 & 1 & 1 (group2) \\
8 & 4 & 2 & $1=2+1=3$ \\
1 & 1 & 0 & 1 (group1) \\
8 & 4 & 2 & $1=8+4+1=13$ (D) \\
Therefore; $35_{8}=3 \mathrm{D}_{16}$ &
\end{tabular}

(10) Conversion from hexadecimal numbers to binary numbers.

Express the binary number in each hexadecimal, and combined.

Example: $3 \mathrm{D} 16=(?) 2$

$\begin{array}{llll}3 & & \\ 8 & 4 & 2 & 1 \\ 0 & 0 & 1 & 1=3 \\ \mathrm{D}(13) & & 1 \\ 8 & 4 & 2 & 1=13(\mathrm{D}) \\ 1 & 1 & 0 & 1=11101_{2}\end{array}$

(11) Conversion from hexadecimal to octal numbers.

Express the binary number in each hexadecimal, combined, and used conversion (3). 
Example: A716 $=(?) 8$

\begin{tabular}{|c|c|c|}
\hline A & & \\
\hline $\begin{array}{ll}8 & 4\end{array}$ & 2 & 1 \\
\hline 10 & 1 & $0=\mathrm{A}(10)$ \\
\hline 7 & & \\
\hline 4 & 2 & 1 \\
\hline $\begin{array}{ll}0 & 1\end{array}$ & 1 & $1=7$ \\
\hline 1 & & \\
\hline 2 & $1=$ & \\
\hline 0 & & \\
\hline 2 & $1=$ & \\
\hline 1 & & \\
\hline 32 & $1=$ & \\
\hline
\end{tabular}

Therefore; $\mathrm{A} 7_{16}=237_{8}$

(12) Conversion from hexadecimal to decimal.

Express the binary number in each hexadecimal, combined, and apply conversion (1).

Example: $3 \mathrm{D} 16=(?) 10$

111101

$\begin{array}{lcrrrr}1 & 1 & 1 & 1 & 0 & 1 \\ 32 & 16 & 8 & 4 & 2 & 1 \\ = & 32+16+8+4+1 & & & \\ = & \end{array}$

Therefore; $3 \mathrm{D}_{16}=61_{10}$

\section{MATERIALS \& PROCEDURES}

\subsection{Respondents}

Study was conducted in Eastern Samar State University, Main Campus, Borongan City, Eastern Samar. Respondents were 15 faculty members in the College of Computer Studies, and 85 students from junior and senior students attaining the degree in Bachelor of Science in Computer Science, Bachelor of Science in Information Technology, and Bachelor of Science in Computer Engineering.

\subsection{Instrument}

Survey questionnaire in instructional assessment tool was employed using the attributes of reliability, usability, and efficiency. Description from these attributes are based in instructional evaluation system template by Glade 2015-2016.

\subsection{Statistical treatment}

Average weighted mean was used in determining the extent of applicability of simplified theorem from the described attributes, while frequency percentage distribution was applied on the applicability of the theorem as instruction.

The following mean values and qualitative descriptions were used to determine its extent of applicability of the attributes described.

$\begin{array}{ll}\text { Mean Value } & \text { Qualitative Description } \\ 4.10-5.00 & \text { Strongly Agree } \\ 3.10-4.00 & \text { Agree } \\ 2.10-3.00 & \text { Slightly Agree } \\ 1.10-2.00 & \text { Disagree } \\ 0.00-1.00 \text { Strongly } & \text { Disagree }\end{array}$

\section{RESULTS \& DISCUSSION}

Table 1.0. Frequency Distribution of Respondent's Perception on the Attributes of the Simplified Theorem

\begin{tabular}{|c|c|c|c|c|c|c|c|}
\hline $\begin{array}{l}\text { Metrics of } \\
\text { Theorem }\end{array}$ & \multicolumn{7}{|c|}{ Rating } \\
\hline $\begin{array}{l}\text { Optional } \\
\text { Parameter } \\
\text { s }\end{array}$ & $\begin{array}{l}\text { SA } \\
\text { (5) }\end{array}$ & $\begin{array}{l}\text { A } \\
(4 \\
)\end{array}$ & $\begin{array}{c}\text { SL } \\
\text { A } \\
\text { (3) }\end{array}$ & $\begin{array}{l}\text { D } \\
(2)\end{array}$ & $\begin{array}{l}\text { SD } \\
\text { (1) }\end{array}$ & $\begin{array}{l}\text { W } \\
\text { eig } \\
\text { ht } \\
\text { ed } \\
\text { M } \\
\text { ea } \\
\text { n }\end{array}$ & $\begin{array}{l}\text { Interpr } \\
\text { etation }\end{array}$ \\
\hline \multicolumn{8}{|l|}{ Reliability } \\
\hline $\begin{array}{l}\text { The } \\
\text { theorem is } \\
\text { free from } \\
\text { errors in } \\
\text { conversion. }\end{array}$ & 73 & 18 & 8 & 1 & 0 & $\begin{array}{l}4.6 \\
3\end{array}$ & $\begin{array}{l}\text { Strongly } \\
\text { Agree }\end{array}$ \\
\hline $\begin{array}{l}\text { The } \\
\text { theorem } \\
\text { validates } \\
\text { inputs. }\end{array}$ & 87 & 10 & 1 & 2 & 0 & $\begin{array}{l}4.8 \\
2\end{array}$ & $\begin{array}{l}\text { Strongly } \\
\text { Agree }\end{array}$ \\
\hline $\begin{array}{l}\text { The } \\
\text { theorem } \\
\text { provides } \\
\text { accurate } \\
\text { and timely } \\
\text { information }\end{array}$ & 79 & 20 & 1 & 0 & 0 & $\begin{array}{l}4.7 \\
8\end{array}$ & $\begin{array}{l}\text { Strongly } \\
\text { Agree }\end{array}$ \\
\hline $\begin{array}{l}\text { The } \\
\text { theorem } \\
\text { engage in } \\
\text { continuing } \\
\text { improveme } \\
\text { nt of } \\
\text { knowledge } \\
\text { and skills. }\end{array}$ & 88 & 10 & 2 & 0 & 0 & $\begin{array}{l}4.8 \\
6\end{array}$ & $\begin{array}{l}\text { Strongly } \\
\text { Agree }\end{array}$ \\
\hline $\begin{array}{l}\text { The } \\
\text { theorem } \\
\text { can keep } \\
\text { abreast of } \\
\text { developme } \\
\text { nts in } \\
\text { instructiona } \\
1 \\
\text { methodolog } \\
\text { y, learning } \\
\text { theory, and } \\
\text { course } \\
\text { content. }\end{array}$ & 63 & 20 & 15 & 2 & 0 & $\begin{array}{l}4.4 \\
4\end{array}$ & $\begin{array}{l}\text { Strongly } \\
\text { Agree }\end{array}$ \\
\hline \multicolumn{8}{|l|}{ Usability } \\
\hline $\begin{array}{l}\text { The } \\
\text { theorem is } \\
\text { acceptable. }\end{array}$ & 95 & 5 & 0 & 0 & 0 & $\begin{array}{l}4.9 \\
5\end{array}$ & $\begin{array}{l}\text { Strongly } \\
\text { Agree }\end{array}$ \\
\hline $\begin{array}{l}\text { The } \\
\text { theorem is } \\
\text { easy to } \\
\text { learn and to } \\
\text { operate. }\end{array}$ & 99 & 1 & 0 & 0 & 0 & $\begin{array}{l}4.9 \\
9\end{array}$ & $\begin{array}{l}\text { Strongly } \\
\text { Agree }\end{array}$ \\
\hline $\begin{array}{l}\text { The } \\
\text { theorem } \\
\text { works with }\end{array}$ & 85 & 10 & 5 & 0 & 0 & $\begin{array}{l}4.8 \\
0\end{array}$ & $\begin{array}{l}\text { Strongly } \\
\text { Agree }\end{array}$ \\
\hline
\end{tabular}




\begin{tabular}{|c|c|c|c|c|c|c|c|}
\hline $\begin{array}{l}\text { or without } \\
\text { technical } \\
\text { support. }\end{array}$ & & & & & & & \\
\hline \multicolumn{8}{|l|}{ Efficiency } \\
\hline $\begin{array}{l}\text { The } \\
\text { theorem } \\
\text { measures } \\
\text { the extent } \\
\text { to which } \\
\text { input is } \\
\text { well used } \\
\text { for an } \\
\text { intended } \\
\text { operation } \\
\text { of number } \\
\text { system } \\
\text { conversion. }\end{array}$ & 80 & 12 & 5 & 3 & 0 & $\begin{array}{l}4.6 \\
9\end{array}$ & $\begin{array}{l}\text { Strongly } \\
\text { Agree }\end{array}$ \\
\hline $\begin{array}{l}\text { Has an } \\
\text { attribute to } \\
\text { comprise } \\
\text { the } \\
\text { capability } \\
\text { of a } \\
\text { specific } \\
\text { application } \\
\text { of effort to } \\
\text { produce a } \\
\text { specific } \\
\text { outcome } \\
\text { with a } \\
\text { minimum } \\
\text { amount or } \\
\text { quantity of } \\
\text { waste of } \\
\text { time or } \\
\text { unnecessar } \\
\text { y effort. }\end{array}$ & 85 & 15 & 0 & 0 & 0 & $\begin{array}{l}4.8 \\
5\end{array}$ & $\begin{array}{l}\text { Strongly } \\
\text { Agree }\end{array}$ \\
\hline $\begin{array}{l}\text { The } \\
\text { theorem } \\
\text { assist } \\
\text { students in } \\
\text { accessing, } \\
\text { interpreting } \\
\text { and } \\
\text { evaluating } \\
\text { information } \\
\text { from } \\
\text { multiple } \\
\text { sources. }\end{array}$ & 82 & 15 & 3 & 0 & 0 & $\begin{array}{l}4.7 \\
9\end{array}$ & $\begin{array}{l}\text { Strongly } \\
\text { Agree }\end{array}$ \\
\hline $\begin{array}{l}\text { The } \\
\text { theorem } \\
\text { provide } \\
\text { quality } \\
\text { work for } \\
\text { students } \\
\text { which is } \\
\text { focused on } \\
\text { meaningful, } \\
\text { relevant, } \\
\text { and } \\
\text { engaging } \\
\text { learning } \\
\text { experiences }\end{array}$ & 95 & 5 & 0 & 0 & 0 & $\begin{array}{l}4.9 \\
5\end{array}$ & $\begin{array}{l}\text { Strongly } \\
\text { Agree }\end{array}$ \\
\hline
\end{tabular}

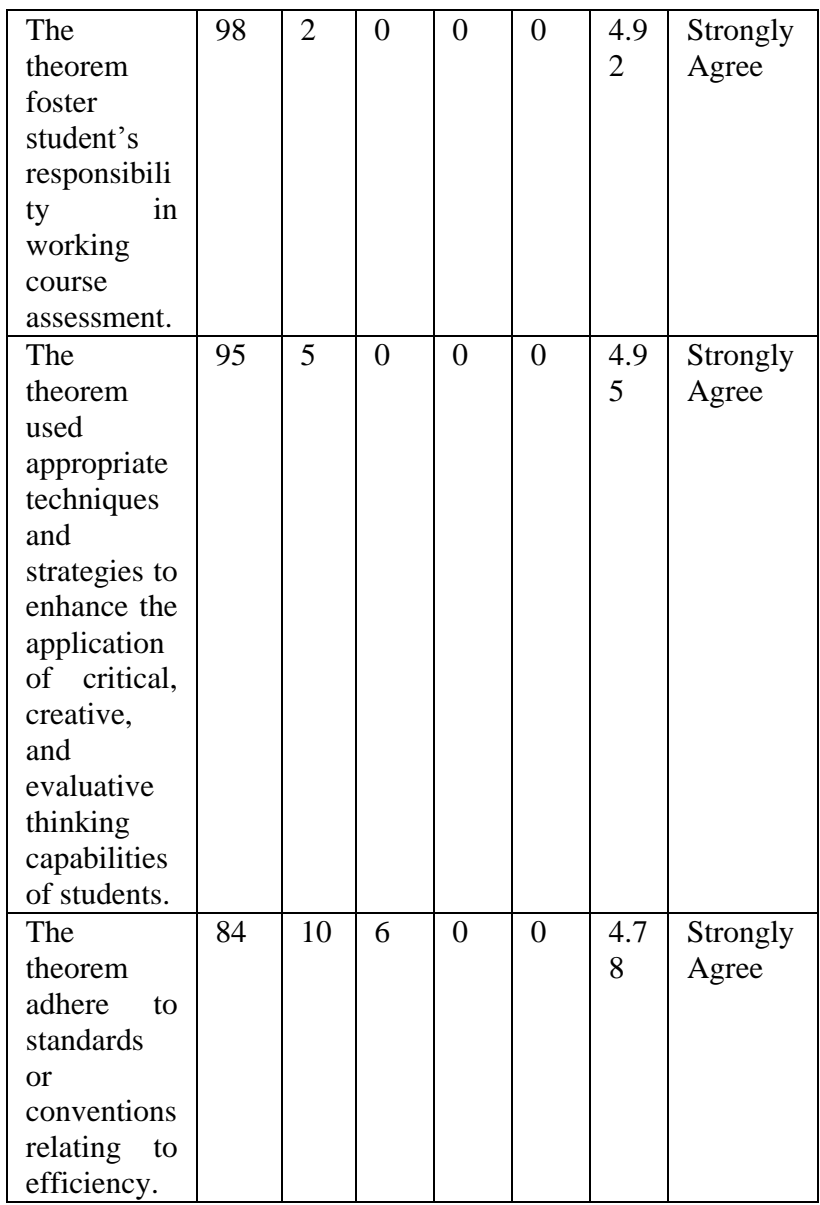

Table 2.0. Average Weighted Mean of Respondent's Perception on the Attributes of the Simplified Theorem

\begin{tabular}{|l|l|l|}
\hline $\begin{array}{l}\text { Theorem } \\
\text { Attributes }\end{array}$ & $\begin{array}{l}\text { Average } \\
\text { Weighted } \\
\text { Mean }\end{array}$ & Interpretation \\
\hline Reliability & 4.70 & $\begin{array}{l}\text { Strongly } \\
\text { Agreed }\end{array}$ \\
\hline Usability & 4.92 & $\begin{array}{l}\text { Strongly } \\
\text { Agreed }\end{array}$ \\
\hline Efficiency & 4.85 & $\begin{array}{l}\text { Strongly } \\
\text { Agreed }\end{array}$ \\
\hline
\end{tabular}

The simplified theorem is very useful in Discrete Structures and Discrete Mathematics in computing courses. Easy to learn and to apply. In fact the usability attribute of the theorem got the highest average weighted mean among the three attributes. Moreover, the simplified theorem characteristically reliable, usable, and efficient. From description of the attributes of the simplified theorem interpreted as "strongly agree". 
Table 3.0 Percentage Distribution of Respondents' on the instruction applicability of the theorem

\begin{tabular}{|l|c|c|c|}
\hline $\begin{array}{l}\text { Mandatory } \\
\text { Parameter }\end{array}$ & Yes & No & $\begin{array}{c}\text { Interpretatio } \\
\text { n }\end{array}$ \\
\hline $\begin{array}{l}\text { Simplified theorem } \\
\text { is applicable } \\
\text { instruction in the } \\
\text { College. }\end{array}$ & $98 \%$ & $2 \%$ & Applicable \\
\hline
\end{tabular}

The innovated simplified theorem is applicable as instruction to the College of Computer Studies gleaned above average of $98 \%$.

\section{CONCLUSION}

Based on students and teachers comments the researcher received during the theorem assessment activity, it was concluded that they prefer to use the innovative simplified theorem rather than what is on the book of references. Innovative theorem was applicable to general education courses and programs, even to non-computing courses for the same purpose. Time efficient and enhanced creative thinking.
The formula supports and supplied the computation to another computation or formula. Secondary curriculum can adapt the uncomplicated tool for instruction purposes.

\section{REFERENCES}

[1] Jaris, Janet. 2015. Instructional Evaluation System Template, Glade 2015-2015. Florida, USA.

[2] Khan, Jhawad. 2013. Number System in Computer.

[3] Killian, Jason. 2012. Numbers Systems: An Introduction to Binary, Hexadecimal, and more.

[4] Demodharana V.S., ACCA. 2013. Innovative Method of Teaching. University of Arizona.

[5] Hyttel, Hans. 2013. "What is the most powerful innovative idea/technique/principle ever used in mathematical proof?" Clark University.

[6] Applying Gardner's Theory of Multiple Intelligence to Mathematics .2015.

[7] Gardner, H. 1991. The unschooled mind. New York. 